\title{
35 years behind the scenes: range extension of the rare Gro's manticore, Morunasaurus groi (Squamata, Hoplocercidae), in Colombia
}

\author{
Juan Daniel Vásquez-Restrepo ${ }^{1}$ \\ 1 Universidad Nacional Autónoma de México (UNAM), Instituto de Geología, Programa de Posgrado en Ciencias Biológicas. \\ Ciudad de México, México. ORCID: http://orcid.org/0000-0002-8306-408X. E-mail: juanda037@outlook.com
}

\begin{abstract}
Morunasaurus is a genus of Neotropical iguanid lizards of the family Hoplocercidae, inhabiting Central and northwestern South America. Their phylogenetic relationships are not completely clear but being presumably paraphyletic. Its type species, M. groi, is very rare, known only from two single localities and a handful of specimens. Here I report a new occurrence of this species for Colombia, which constitutes the southeastern record to the date, extending the species range by about $175 \mathrm{~km}$ and $510 \mathrm{~m}$ altitudinally. Additionally, I discuss about the intraspecific differences in coloration between Panamanian and Colombian specimens.
\end{abstract}

Keywords. Squamata; Iguanidae; Hoplocercidae; Distribution; New record.

\section{INTRODUCTION}

Morunasaurus is a genus of iguanid lizards of the family Hoplocercidae, distributed in the lowlands ( $<1,000 \mathrm{~m}$ a.s.l.) of Panama, Colombia, Ecuador and Peru. They occur both west and east of the Andes, in the Pacific versant and the Amazon foothills, but their distributions are broadly disjunct (Torres-Carvajal et al., 2011). Currently, three species are recognized within the genus: $M$. annularis (O'Shaughnessy, 1881); M. groi Dunn, 1933; and M. peruvianus Köhler, 2003. These lizards seem to be diurnal, ground dwellers and inhabit in burrows, and except for some anecdotal observations about behavior and clutches, most aspects of their natural history are unknown (Dunn, 1933; Corredor et al., 1985; Köhler et al., 1999; Köhler, 2003; Torres-Carvajal et al., 2011). The phylogenetic relationships of Morunasaurus species have been complex and non-conclusive, mainly addressed using external morphology, or partially at genetic level including just the cis-Andean species. Thus, the phylogenetic position of this genus within the Hoplocercidae family and the relationships among their species remain to be clarified (Torres-Carvajal et al., 2011).

Morunasaurus groi is the type species of the genus, and the only one found west of the Andes. This taxon is known from two single localities: Valle de Antón in central Panama (type locality), and Dabeiba municipality, in the Cordillera Occidental of Colombia (Fig. 1). Its elevational range is narrow, stretching from 700 to $805 \mathrm{~m}$ a.s.l. (Medina-Rangel et al., 2015). Currently, M. groi is listed as Endangered (EN) both in national and global assessments (Medina-Rangel et al., 2015; Ibáñez et al., 2016). In Colombia this species was reported for the first time by Corredor et al. (1985), and since then, no new records had been made. This is a rarely documented species, probably due to its secretive habits.

Here, I extend the known distribution of the species, its reported elevational range, and provide new data on external morphology and natural history.

\section{MATERIAL AND METHODS}

Fieldwork was conducted on November 28 of 2020, from 17:00-20:00 hours, during the second rainy season of the year. It was part of an ongoing project of communitarian inventories of biodiversity in the San Carlos municipality, Eastern sub-region of the Antioquia Department. San Carlos has an elevational gradient between 140 and 2,440 $\mathrm{m}$ a.s.l., and the sampling site belongs to the Magdalena's river basin.

A single specimen was collected and euthanized with an overdose of $2 \%$ Roxicaine, fixed in $10 \%$ formalin, and finally preserved in $70 \%$ ethanol. Previously to the fixation, a tissue sample for DNA extraction was taken and stored in non-denaturated absolute ethanol (99\%). Methodology 

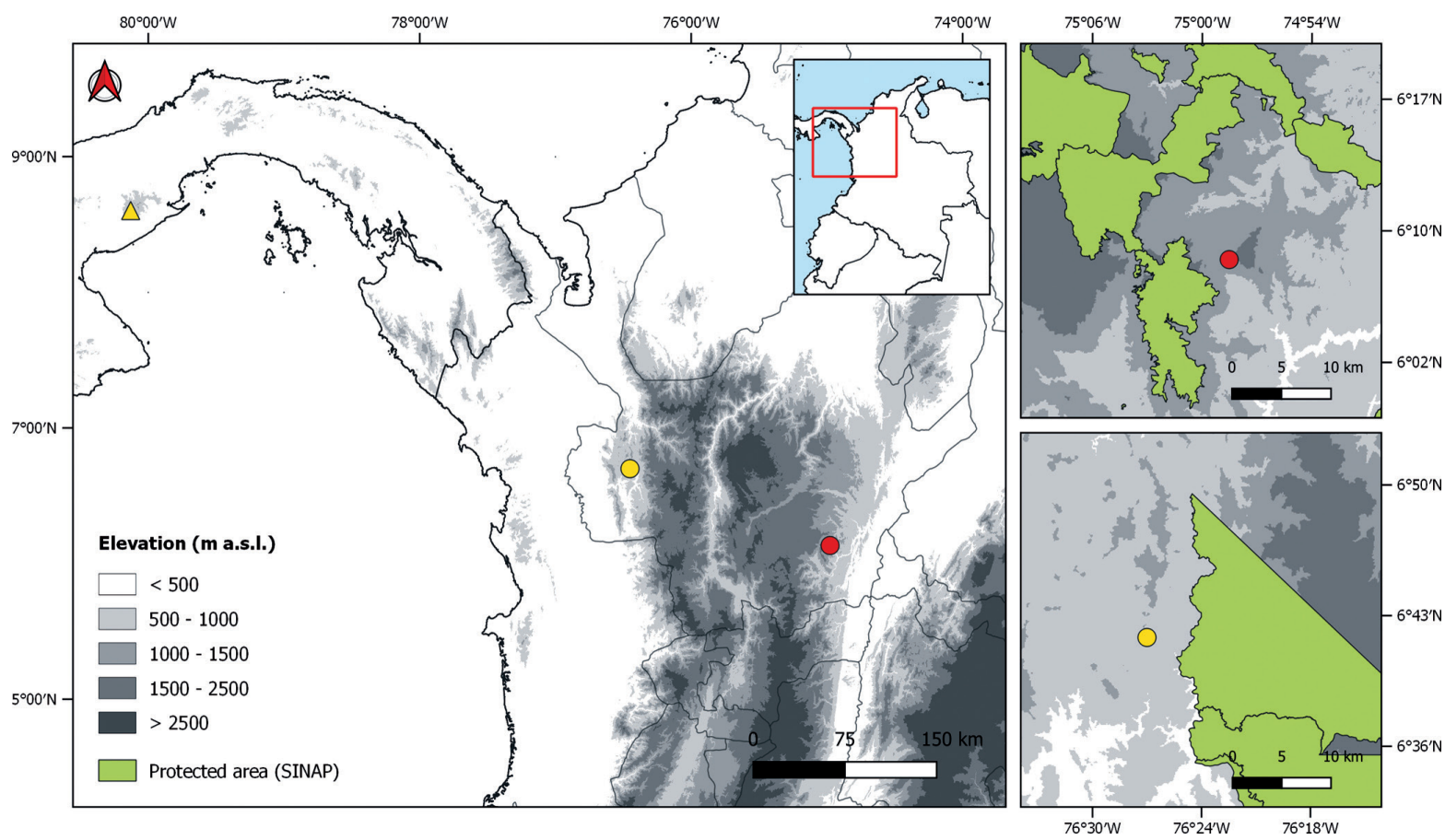

Figure 1. Distribution map of Morunasaurus groi. Yellow symbols are previous records from literature (Dunn, 1933; Corredor et al., 1985; Torres-Carvajal et al., 2011), while red is the new one here presented. Triangle is the type locality. Green polygons are the protected areas in Colombia from SINAP open data (Sistema Nacional de Áreas Protegidas, in Spanish).

of killing and tissue sampling follow Vargas-Ramírez (2017). The specimen was deposited at the Museo de Herpetología Universidad de Antioquia (MHUA). Identification and comparisons follow Corredor et al. (1985) and Torres-Carvajal et al. (2011). General measurements of snout-vent length (SVL) and tail length (TaL) were taken using a ruler. Scutellation is presented as left/ right when not equal for bilateral characters. Sex was determined by subcaudal incision, noting the presence or absence of hemipenes.

\section{RESULTS}

MHUA-R 13735 (Fig. 2): a female, from Quebrada Los Pomos, vereda Santa Rita, San Carlos municipality, Antioquia Department $\left(06^{\circ} 08^{\prime} 01.79^{\prime \prime} \mathrm{N}, 74^{\circ} 58^{\prime} 31.84^{\prime \prime} \mathrm{W}\right.$; WGS84; ca. 1,315 m a.s.I.). SVL $=110 \mathrm{~mm}$, TaL $=140 \mathrm{~mm}$. With $16 / 15$ supralabial scales, first 10 larger followed by small ones; 9/8 large infralabials; nasal enlarged and semi-divided posteriorly; lower orbit bordered by two rows of subequal scales, separating it from the labials; lower eyelid non-transparent and divided in 10 rows of small scales; rostral and mental large and single; 14 (+ one pre) superciliary scales; two small post-mental scales, followed by three scales larger than adjacent; scales below head small and projected posteriorly; small gular fold; dorsal granular, mixed with spine-like scales, larger to the posterior region of body and tail; without a large scale row in the midline; dorsolaterally with two well-defined longitudinal lines of spine-like scales, from the upper posterior edge of the ear and along the body; below those lines, spine-like scales smaller and disposed vertical or obliquely; above them, spine-like larger and

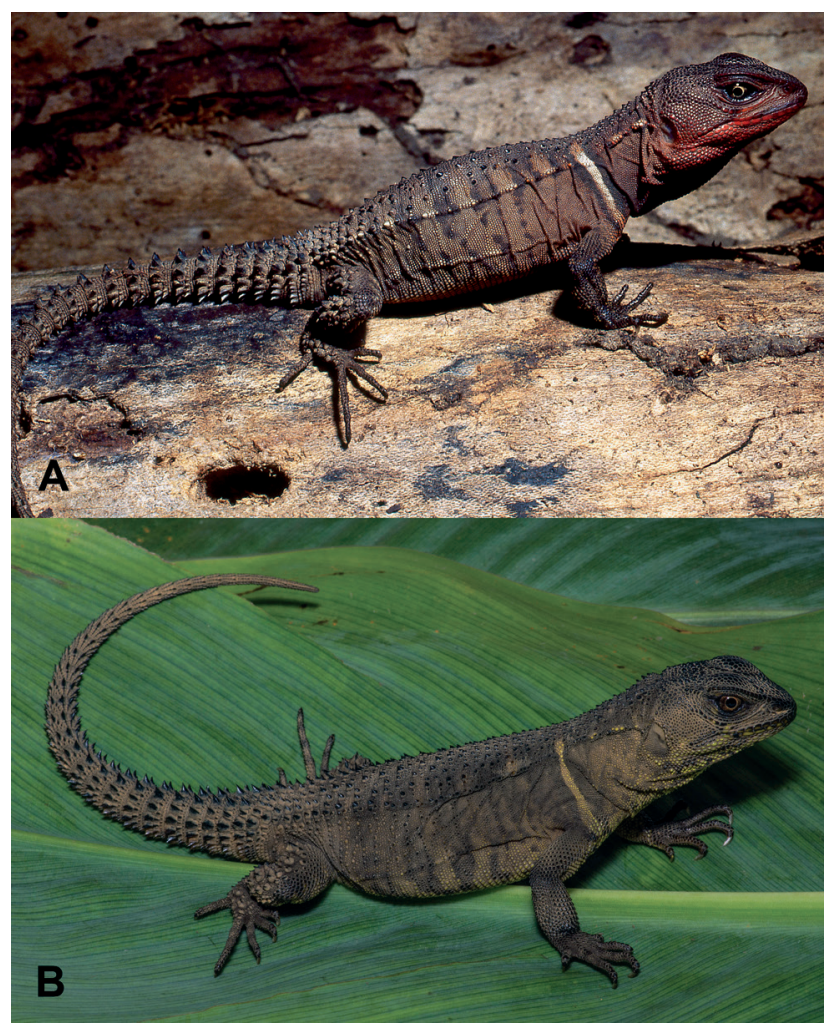

Figure 2. Morunasaurus groi in life. (A) Adult male from Dabeiba municipality, Antioquia Department (ICN 6101). (B) Adult female from San Carlos municipality, Antioquia (MHUA-R 13735). Notice the sexual dimorphism in throat coloration. Male's photo courtesy of Juan M. Renjifo.

alternating; ventral scales rounded squares, juxtaposed, non-keeled but some projected posteriorly, smaller to gular and anal region; four femoral pores (by side); posterior upper surfaces of the hindlimbs also with enlarged 
spines; 20 scales under $4^{\text {th }}$ finger; $26 / 27$ scales under $4^{\text {th }}$ toe; tail with 34 verticiles, each one formed by four rings of transversal scales, the last one larger and spine-like. In life, dorsum brown, with some yellowish reticulations on the flanks (Fig. 3A), with an incomplete yellowish band on both sides extending from shoulder to scapular region; ventrally, yellowish spotted with brown from the head to the first one third of the belly, followed by a large white circular area in the second third, and an immaculate yellowish patch to the anal region; tail is cream turning to brown posteriorly and spotted with dark brown (Fig. 3B).

This occurrence is about $175 \mathrm{~km}$ SE from the only other previously known locality in Colombia, constitutes the first one for the Cordillera Central and Magdalena's river basin, and is the southernmost record for the species. Additionally, it extends the altitudinal distribution of the species by about $510 \mathrm{~m}$ upward. This individual was discovered in a burrow at 19:00 hours, after rain and about three meters of a creek. When approaching, it ran away digging into the burrow. After 30 minutes it was partially outside again, exposing its hindlimbs and tail. On caught, this lizard inflated the body filling the empty space of the burrow entrance and nailing its spine-like scales into the walls, making its extraction difficult. The burrow was located among the roots of a small tree, adjacent to a termite mound. During the euthanasia several mites were found inside its mouth, attached to the tongue and palate.

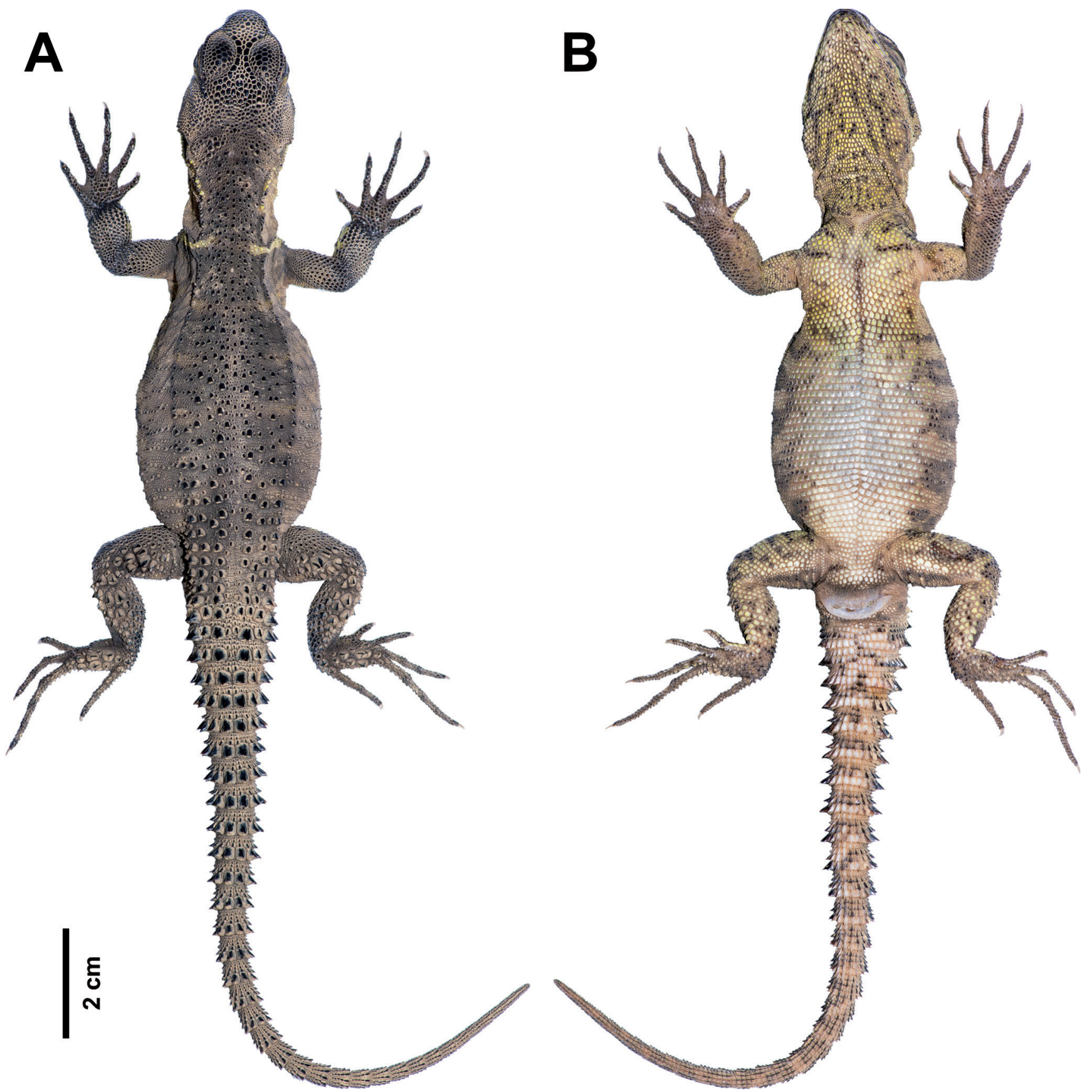

Figure 3. Dorsal (A) and ventral (B) coloration of Morunasaurus groi from the Magdalena's river basin. Photographs were taken post-mortem but immediately after to the euthanasia. 

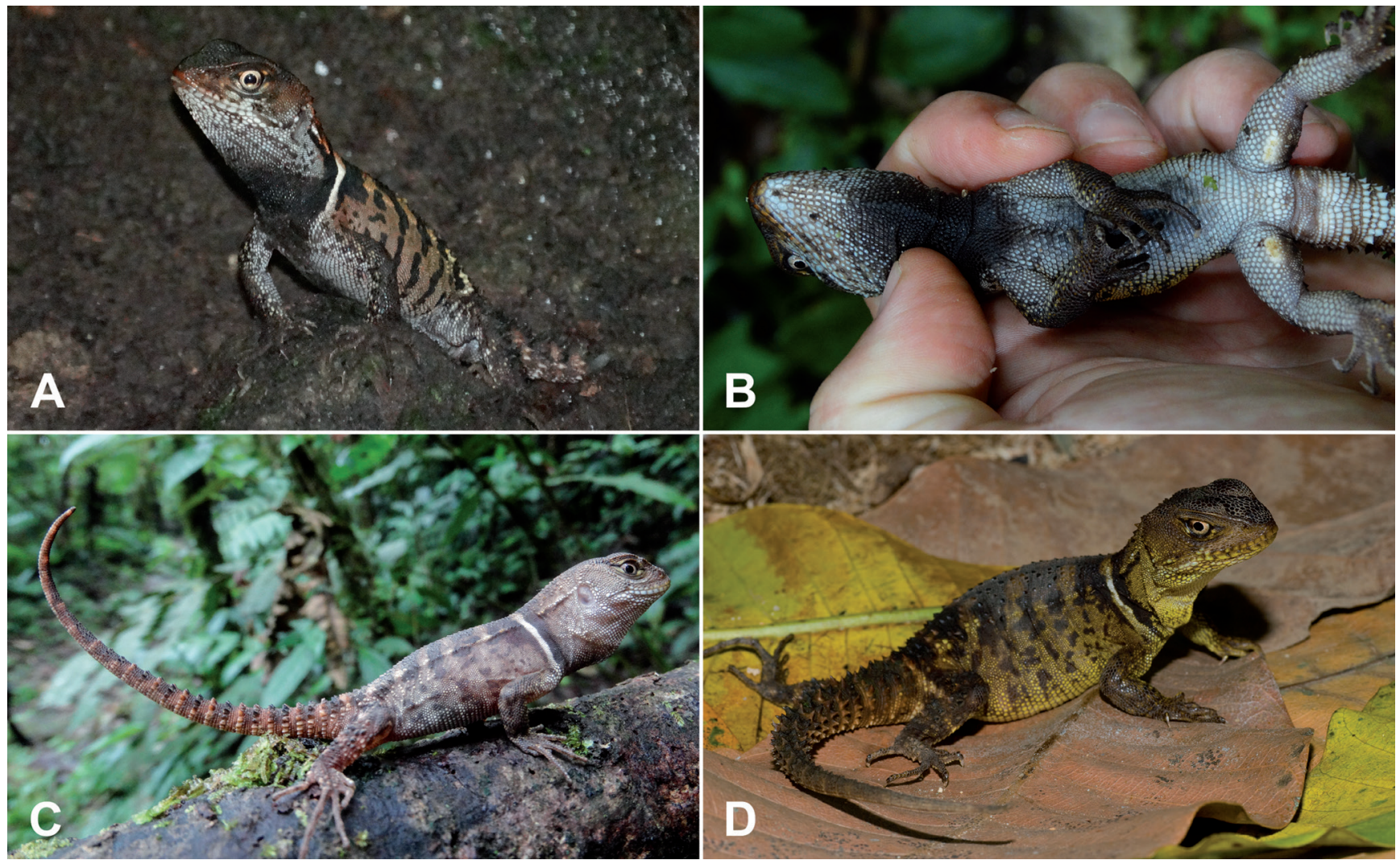

Figure 4. Morunasaurus groi in life from Valle de Antón, Panama (type locality). (A-B) Adult males, (C-D) adult females. Photos: Cesar Barrio-Amorós (A-C), Josh Vandermeulen (D).

\section{DISCUSSION}

The occurrence of Morunasaurus groi in the inter-Andean region constitutes a novel finding since this species seemed to be restricted to the Pacific versant. Despite being one of the few reptiles in a threat category in Colombia (Morales-Betancourt et al., 2015), M. groi is not represented within either the local nor national system of protected areas (Fig. 1). Additionally, protected areas in the vicinity of the extent of this species include mainly moderate elevation and highlands (> 1,000 m), leaving outside most of the span where $M$. groi is known to be more common. On the other hand, it is not a secret that many groups of reptiles are poorly studied, since species lifestyles and site inaccessibility may bias the sampling efforts. Nonetheless, the regional environmental authority has been working in recent years in the preservation of some punctual forested areas in Eastern Antioquia, as part of an ongoing project of conservation of wild cats, within which this record was obtained. The aim of these areas is to serve as biological corridors, involving local farmers and providing elements to minimize the human-felid conflict. With rare species, conducting ecological studies in order to define new areas susceptible to conservation is expensive and fruitless in short term. For this reason, the use of umbrella species like big cats (e.g., cougar and jaguars) may constitute the better conservation strategy, since they are wide-spread embracing the small and disjunct distribution of these secretive reptiles, and are more charismatic, facilitating the obtaining of resources and the reception of the communities.
Lepidosis and scale arrangements of this inter-Andean specimen allocate it within M. groi (Torres-Carvajal et al., 2011). Interestingly, this female presents femoral pores, a character apparently restricted to males (Corredor et al., 1985; Torres-Carvajal et al., 2011). Nevertheless, there is an evident difference in coloration between Panamanian and Colombian specimens. According to Dunn's (1933) original description, individuals from the type locality are as follow: brown above with obscure black crossbars; a white black-bordered bar on side of the neck; and ventrally gray, with the throat and center of the belly black in males (Fig. 4 A-D). In contrast, Colombian specimens are brown with dark brown reticulations; with the chin and infralabial region scarlet red in males and yellowish in females; and ventrally greyish brown or yellowish without the black patch (Figs. 2 and 3; Corredor et al., 1985). Here, I am considering this as geographic intraspecific variation, given the low number of samples, and in the absence of other evidence suggesting they belong to different entities or incomplete separated lineages that may be named as subspecies (de Queiroz, 2020).

The availability of a tissue sample for the type species of Morunasaurus, opens the door to explore thoroughly the phylogenetic relationships among these lizards, since this genus has been suggested to be paraphyletic with respect to Enyalioides and Hoplocercus (Etheridge \& de Queiroz, 1988; Wiens \& Etheridge, 2003; Torres-Carvajal \& de Queiroz, 2009). Even if Colombian populations represented a unique entity other than M. groi from Panama, its morphological resemblance and geographical nearness seem to indicate a close evolutionary relationship 
with the Panamanian populations, and not so close with the cis-Andean (Amazonian) species. For this reason, it is likely that Panamanian and Colombian populations belong to the same lineage, and therefore, this data may be useful to test its monophyly.

Finally, the observations of natural history in Morunasaurus are scarce, and limited to habitat description, flee behavior and clutch size in some species (Dunn, 1933; Corredor et al., 1985; Köhler et al., 1999). The diet of these lizards is unknown, but given the finding of termites inside its mouth, it is feasible they are part of its diet composition. If they are prey specialists or generalists remains unknown.

\section{ACKNOWLEDGMENTS}

This fieldwork was part of the "Convenio 247-2020" between Cornare (Corporación Autónoma Regional de las Cuencas de los Ríos Negro y Nare) and Gobernación de Antioquia. I want to thank to Cornare, for allow me to participate in the communitarian inventories, and for the collecting permission (according to the Colombian law Decree 1376/2013, environmental authorities do not need specific collecting permissions). To Angela Rivero, Catalina Pinzón and Robinson Urrea, for their help with the logistics issues and during the survey. To Juan Manuel Renjifo, Cesar Barrio and Josh Vandermeulen, for the photographs of the Colombian male and Panamanian specimens, respectively. Finally, to Gunther Köhler, Pedro Sales Nunes and the anonymous reviewer, for their valuable comments which helped to improve the quality of this manuscript.

\section{REFERENCES}

Corredor, V.; Renjifo, J.M. \& Ayala, S. 1985. Discovery of Morunasaurus groi Dunn (Sauria: Iguanidae) in northwestern Colombia. Journal of Herpetology, 19(1): 162-164. D0l
Dunn, E.R. 1933. Amphibians and reptiles from El Valle de Antón, Panama. Occasional papers of the Boston Society of Natural History, 8: 65-79.

Etheridge, R. \& de Queiroz, K. 1988. A phylogeny of Iguanidae. In: Estes, R. \& Pregill, G. (Eds.). Phylogenetic relationships of the lizard families. Stanford, California, Stanford University Press. p. 283-367.

Ibáñez, R.; Jaramillo, C.; Castañeda, M.R.; Renjifo, J.; Bolívar, W. \& Velasco, J. 2016. Morunasaurus groi. The IUCN Red List of Threatened Species 2016: e.T203070A2759787. DOI

Köhler, G. 2003. A new species of Morunasaurus from Peru (Reptilia, Squamata, Hoplocercidae). Senckenbergiana Biologica, 82 (1-2): 235-242.

Köhler,G.;Seipp, R.; Moya,S.\&Almendáriz, A. 1999.ZurKenntnisvonMorunasaurus annularis (O'Shaughnessy, 1881). Salamandra, 35(3): 181-190.

Medina-Rangel, G.F.; López-Perilla, Y.R. \& Renjifo, J.M. 2015. Morunasaurus groi (Dunn, 1933). In: Morales-Betancourt, M.A.; Lasso, C.A.; Páez, V.P. \& Bock, B.C. (Eds.). Libro rojo de reptiles de Colombia. Bogotá, Instituto de Investigación de Recursos Biológicos Alexander von Humboldt (IAvH) Universidad de Antioquia.p. 65-67.

Morales-Betancourt, M.A.; Lasso, C.A.; Páez, V.P. \& Bock, B.C. 2015. Libro rojo de reptiles de Colombia. Bogotá, Instituto de Investigación de Recursos Biológicos Alexander von Humboldt \& Universidad de Antioquia.

0'Shaughnessy, A.W.E. 1881. An account of the collection of lizards made by Mr. Buckley in Ecuador, and now in the British Museum, with descriptions of the new species. Proceedings of the Zoological Society of London, 1881: 227-245. DOI

de Queiroz, K. 2020. An updated concept of subspecies resolves a dispute about the taxonomy of incompletely separated lineages. Herpetological Review, 51(3): 459-461.

Torres-Carvajal, 0. \& de Queiroz, K. 2009. Phylogeny of hoplocercine lizards (Squamata: Iguania) with estimates of relative divergence times. Molecular Phylogenetics and Evolution, 50: 31-43. D0I

Torres-Carvajal, 0.; Etheridge, R. \& de Queiroz, K. 2011. A systematic revision of Neotropical lizards in the clade Hoplocercinae (Squamata: Iguania). Zootaxa, 2752: 1-44. D0I

Vargas-Ramírez, M. 2017. Reptiles. In: Gonzalez, M.A. \& Arenas-Castro, H. (Eds.). Recolección de tejidos biológicos para análisis genéticos. Bogotá, Instituto de Investigación de Recursos Biológicos Alexander von Humboldt. p. 25-26.

Wiens, J.J. \& Etheridge, R. 2003. Phylogenetic relationships of hoplocercid lizards: Coding and combining meristic, morphometric, and polymorphic data using step matrices. Herpetologica, 59(3): 375-398. DOI 